\title{
Preparation, Characterisation and Evaluation of Brazilian Clay-Based Catalysts for use in Esterification Reactions
}

\author{
Michelle J. C. Rezende, ${ }^{*, a}$ Mírian S. C. Pereira, ${ }^{b}$ Gabriel F. N. Santos, ${ }^{b}$ Gabriel O. P. Aroeira, ${ }^{a}$ \\ Tiago C. Albuquerque Jr., ${ }^{a}$ Paulo A. Z. Suarez ${ }^{b}$ and Angelo C. Pinto ${ }^{a}$ \\ anstituto de Química, Universidade Federal do Rio de Janeiro, Cidade Universitária, \\ CT, Bloco A, 21941-909 Rio de Janeiro-RJ, Brazil \\ ${ }^{b}$ Instituto de Química, Universidade de Brasília, Campus Universitário Darcy Ribeiro, \\ CP 4478, 70904-970 Brasília-DF, Brazil
}

\begin{abstract}
Catalisadores a base de argilas naturais brasileiras foram preparados, caracterizados, e sua atividade catalítica foi avaliada em reações de esterificação. As argilas naturais foram ativadas por tratamento ácido como recebidas, sem qualquer tratamento prévio. As argilas naturais e as argilas ácidas foram caracterizadas por DRX, TPD- $\mathrm{NH}_{3}$, termodessorção de $n$-butilamina, análise de adsorção de $\mathrm{N}_{2}$, FT-IR, TGA e DTA. O desempenho catalítico foi investigado em reações de esterificação de diversos ácidos carboxílicos com diferentes álcoois. As reações foram realizadas com razão molar ácido carboxílico/álcool $1: 3$, a $100{ }^{\circ} \mathrm{C}$ e pressão atmosférica, por $3 \mathrm{~h}$. As argilas ácidas forneceram boas conversões e apresentaram desempenho melhor que a argila comercial K10.

Natural Brazilian clay-based catalysts were prepared, characterised, and their catalytic activity was assessed in esterification reactions. The natural clays were acid activated as received, without any previous treatment. Both natural and acid-activated clays were characterised by XRD, $\mathrm{NH}_{3}$-TPD, thermodesorption of $n$-butylamine, $\mathrm{N}_{2}$ adsorption analysis, FT-IR, TGA and DTA. The catalytic performance was investigated in the esterification of several carboxylic acids with different alcohols. The reactions were carried out in a 1:3 carboxylic acid/alcohol molar ratio at $100{ }^{\circ} \mathrm{C}$ and atmospheric pressure for $3 \mathrm{~h}$. The acid-activated clays provided good yields and better performance than commercial clay K10.
\end{abstract}

Keywords: acid activation, clay, smectite, esterification

\section{Introduction}

Esterification reactions are widely employed in a variety of chemical industries. ${ }^{1}$ The procedure generally uses either sulfuric, hydrochloric or sulfonic acid as catalyst. These catalysts generate large quantities of acidic waste, which require appropriate treatment before disposal. The most widely used catalyst is sulfuric acid. It is a low cost reagent and is very active. However, it is also corrosive and presents problems of storage and control. $^{2}$

To minimise the problems associated with the homogeneous process, intensive research has been recently devoted to the development of heterogeneous catalysts for esterification. Some examples include functionalised

*e-mail: mjcrezende@gmail.com mesoporous materials, ${ }^{3,4}$ ion-exchange resin, ${ }^{1}$ oxides $^{5-7}$ and metal complexes. ${ }^{8,9}$

There is considerable interest in developing catalysts based on clays. In terms of their environmental aspect, these materials are one of the most friendly solid catalysts. Additionally, clay-based catalysts are very promising because of the low cost of the raw material, ease of properties manipulation and ease of recovery and reuse. ${ }^{10}$ Ion exchange capacity and the potential for increased interlayer spacing are important characteristics of clay minerals that strongly influence their physical-chemical and technological properties. These characteristics, as well as their high surface area, have lead clay minerals to be explored as catalysts. The acid activation method is usually employed to modify the textural characteristics of clays.

Clays are being employed successfully in many organic reactions, and smectites are most often used. ${ }^{11-17}$ 
There have also been studies using other minerals. ${ }^{18-21}$ With respect to esterification, some studies have used commercial, metal-exchanged and heteropoly acid supported montmorillonite. ${ }^{22-28} \mathrm{We}$ report here the preparation, characterisation and catalytic activity of two Brazilian clay-based catalysts in esterification reactions at atmospheric pressure and without a Dean-Stark apparatus or co-solvent.

\section{Experimental}

\section{Materials}

The two natural clays were from Boa Vista District, Paraíba, Brazil. Sulfuric acid, lauric acid, sodium sulfate, hexanol and cyclohexanol were purchased from Vetec (Brazil). $n$-Butylamine, phenylacetic, benzoic and cyclohexanoic acids were from Aldrich (USA). Ethyl acetate, hexane and methanol were from Tedia (Brazil) and silica gel (70-230 mesh) was from Merck (USA).

\section{Catalysts preparation}

The two clays were completely crushed and passed through a 60 mesh sieve. The homogenised clays, called BBn and VLn, were acid-activated, without any previous treatment, in a round-bottom flask connected to a reflux condenser. ${ }^{29} \mathrm{~A} 10 \% \mathrm{~m} / \mathrm{v}$ suspension of clay in $4 \mathrm{~mol} \mathrm{~L} \mathrm{~L}^{-1}$ sulfuric acid was stirred at $90{ }^{\circ} \mathrm{C}$ for $2 \mathrm{~h}$. The solid was filtered under reduced pressure and washed with distilled water until the washing water has the same $\mathrm{pH}$ of the first. The material was dried in an oven at $110^{\circ} \mathrm{C}$ for $24 \mathrm{~h}$ and finally ground until passage through a 60 mesh sieve again. The activated clays, called BBa and VLa, were kept in a dessicator.

\section{Catalysts characterisation}

XRD analysis was performed on a Rigaku D/Max-2A/C with $\mathrm{Cu}-\mathrm{K} \alpha(\lambda=1.5406 \AA)$ at $40 \mathrm{kV}$ and $20 \mathrm{~mA}$. A $2 \theta$ range from $5^{\circ}$ to $80^{\circ}$ was scanned at $0.02^{\circ} \mathrm{s}^{-1}$. BET specific surface area was measured by nitrogen adsorption data in a relative pressure range from 0.05 to 0.98 , employing a Quantachrome NOVA 2200e. The average distribution of pore sizes was calculated using the BJH method. All of the adsorption and desorption isotherms were obtained at the temperature of $-196^{\circ} \mathrm{C}$. Prior to each measurement, all samples were degassed at $110{ }^{\circ} \mathrm{C}$ for $5 \mathrm{~h}$ under vacuum.

Temperature programmed desorption of ammonia $\left(\mathrm{NH}_{3}-\mathrm{TPD}\right)$ was performed using a CHEMBET-3000 apparatus (American Quantachrome Company). Each sample was treated at $250{ }^{\circ} \mathrm{C}$ for 50 min under a constant flow of helium $\left(80 \mathrm{~mL} \mathrm{~min}^{-1}\right)$ prior to $\mathrm{NH}_{3}$ adsorption. The TPD spectrum was obtained across a temperature increase from $100{ }^{\circ} \mathrm{C}$ up to $800{ }^{\circ} \mathrm{C}$ at a rate of $15{ }^{\circ} \mathrm{C} \mathrm{min}-1$. The desorbed $\mathrm{NH}_{3}$ was detected by a thermal detector.

The number of acid sites was estimated by thermodesorption of $n$-butylamine. Each sample was heated to $120{ }^{\circ} \mathrm{C}$ at a rate of $10{ }^{\circ} \mathrm{C} \mathrm{min}-1$ under He flow at $40 \mathrm{~mL} \mathrm{~min}{ }^{-1}$. After $30 \mathrm{~min}$ at $120{ }^{\circ} \mathrm{C}$, the material was kept under He flow saturated with $n$-butylamine for 10 min. Next, pure $\mathrm{N}_{2}$ percolated the sample during $20 \mathrm{~min}$ to remove any physiosorbed $n$-butylamine molecules. Thermogravimetric results were obtained under $\mathrm{N}_{2}$ flow at $20 \mathrm{~mL} \mathrm{~min}^{-1}$ from 20 up to $800{ }^{\circ} \mathrm{C}$ at a rate of $10{ }^{\circ} \mathrm{C} \mathrm{min}^{-1}$, on a TGA-51 Shimadzu.

The thermal analysis (TGA and DTA) was done on a DTG-60 Shimadzu instrument under $\mathrm{N}_{2}$ flow $\left(50 \mathrm{~mL} \mathrm{~min}^{-1}\right)$. The samples were analysed from 25 to $1000^{\circ} \mathrm{C}$ at a rate of $20^{\circ} \mathrm{C} \mathrm{min}^{-1}$. The thermal analyser was a TA-60WS.

The infrared spectrum was obtained from a powder sample and $\mathrm{KBr}$ pellets. The analysis was performed on a Bruker Equinox 55 interferometer (Ettlingen, Germany) using a DTGS detector. The FT-IR spectrum in the range 4000 to $400 \mathrm{~cm}^{-1}$ is the average of 32 scans at a nominal spectral resolution of $4 \mathrm{~cm}^{-1}$.

\section{Esterification reactions}

The catalysts were pre-activated in a microwave oven at $760 \mathrm{~W}$ for $5 \mathrm{~min}$ immediately before the catalytic test. This activation method does not modify the crystalline structure and the catalytic properties of clays. ${ }^{30}$ The reaction medium was composed of carboxylic acid $(4 \mathrm{mmol})$, alcohol $(12 \mathrm{mmol})$ and catalyst $(200 \mathrm{mg})$. The reaction was carried out in a $5 \mathrm{~mL}$ round-bottom flask connected to a reflux condenser and immersed in a heating bath at $100{ }^{\circ} \mathrm{C}$. The suspension was kept under constant stirring at atmospheric pressure. After $3 \mathrm{~h}$, the reaction mixture was cooled and ethyl acetate was added to extract the products. The catalyst was filtered; the organic layer was dried over anhydrous sodium sulfate and evaporated under reduced pressure. All of the reactions were performed in duplicate.

\section{Conversion calculation}

The conversion to ester was analysed by gas chromatography using a flame ionisation detector in a Hewlett Packard 5890 series II. A 25 m Carbowax 20M column with $0.2 \mathrm{~mm}$ i.d. and $0.2 \mu \mathrm{m}$ phase film diameter was used. The carrier gas was hydrogen at a flow rate of $1.2 \mathrm{~mL} \mathrm{~min}{ }^{-1}$. The temperature program was $140{ }^{\circ} \mathrm{C}$ 
to $180{ }^{\circ} \mathrm{C}$ at a rate of $10^{\circ} \mathrm{C} \mathrm{min}{ }^{-1}$, followed by a second rate of $3{ }^{\circ} \mathrm{C} \mathrm{min}{ }^{-1}$ up to $220{ }^{\circ} \mathrm{C}$. The injector and detector temperatures were held at $240{ }^{\circ} \mathrm{C}$. A sample volume of $1.0 \mu \mathrm{L}$ and the split mode with a 1:20 ratio were used.

The conversion to ester was determined by the internal standard (IS) addition method. Pentadecanoyl propanoate was used as IS. ${ }^{31}$ The response factors were calculated for the carboxylic acids and for their esters. The ester standards were obtained by esterification using sulfuric acid as a catalyst. The product was purified by column chromatography over silica gel using hexane/ethyl acetate 8:1 as the eluent. GC-FID analyses indicated that the ester standards were more than $99 \%$ pure.

The standard solutions (acid and ester) and the sample solutions were prepared by mixing $10 \mathrm{mg}$ of the standard (or reaction product) with $250 \mu \mathrm{L}$ of $5000 \mathrm{mg} \mathrm{L}^{-1} \mathrm{IS}$ solution and completing the volume to $5 \mathrm{~mL}$ with ethyl acetate.

\section{Results and Discussion}

Natural Brazilian clays were used without any previous treatment to eliminate organic materials, quartz, other materials or minerals. The objective was to simplify the preparation of clay-based catalysts to evaluate their potential for use in esterification reactions. Of course, for industrial use of these catalysts a deeply study is needed in order to evaluate the differences in the catalytic activity according to the composition of the clay which may vary in the mining site.

\section{Characterisation of the catalysts}

Figure 1 indicates the XRD patterns of the clays. As can be seen, the XRD shows a mixture of different minerals. The natural clays presented reflections at

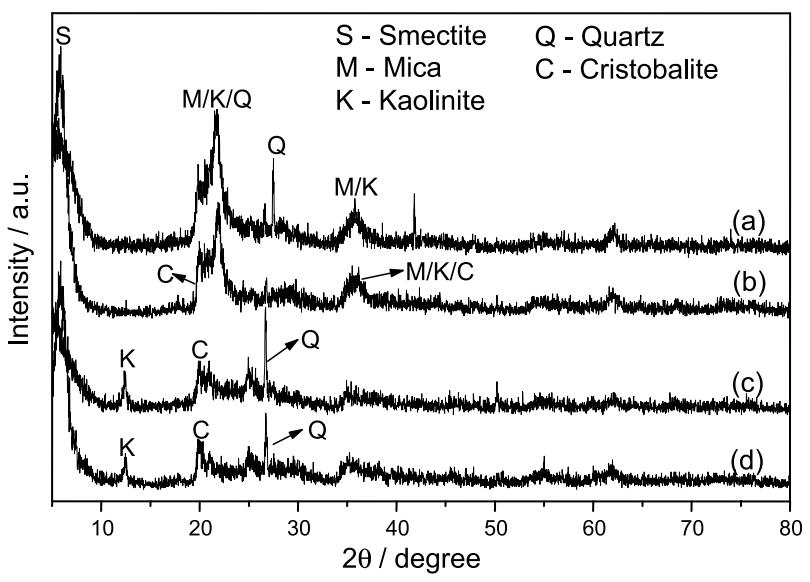

Figure 1. XRD diffraction patterns of clays: (a) BBa, (b) BBn, (c) VLa, (d) VLn.
$14.9 \AA\left(2 \theta=5.9^{\circ}\right)$, typical of smectite. The XRD analyses indicated that smectite is the dominant mineral in the two natural clays. The peaks at $2 \theta=22.3^{\circ}$ and $27.5^{\circ}$ suggest the presence of quartz in the raw materials. Kaolinite $\left(2 \theta=12.5^{\circ}\right)$, mica $\left(2 \theta=22.3^{\circ}\right)$ and cristobalite $\left(2 \theta=20.8^{\circ}\right)$ may also be present.

The characterization of smectite was confirmed by the expansion of the interlayer distance by treatment with ethylene glycol. A heat treatment at $550^{\circ} \mathrm{C}$ was also used to check the collapse of the structure. The XRD analyses indicated a peak at $17.2 \AA\left(2 \theta=5.1^{\circ}\right)$ after the first treatment and a breakdown to $10.3 \AA\left(2 \theta=8.5^{\circ}\right)$ after heating.

XRD analyses of the acid-activated clays BBa and VLa revealed that the $\mathrm{d}(001)$ smectite peak at $2 \theta=5.9^{\circ}$ was of a lower intensity compared with the natural samples, suggesting a partial destruction of the crystalline phase of the clays after acid treatment.

Nitrogen adsorption isotherms for the samples are indicated in Figure 2. All of the isotherms exhibit stepwise adsorption and desorption (type IV isotherms), indicating a typical mesoporous structure. The textural data are displayed in Table 1 and indicate that the surface area increased dramatically with the acid treatment. The maximum BET surface area with the maximum pore size occurred in $\mathrm{VLa}\left(238 \mathrm{~m}^{2} \mathrm{~g}^{-1}\right)$. The corresponding pore size distributions indicate the presence of mesoporosity in the clays. The hysteresis loop observed in the isotherm can be classified as $\mathrm{H} 4$ type in the IUPAC system. This H4 hysteresis loop indicates that the structures are mesoporous, reinforcing the isotherm data.

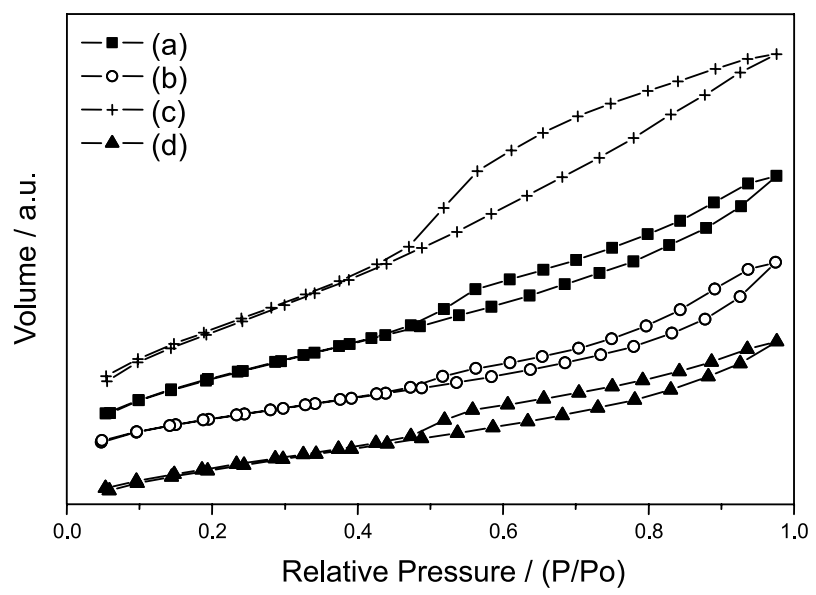

Figure 2. $\mathrm{N}_{2}$ adsorption-desorption isotherms: (a) BBa, (b) BBn, (c) VLa, (d) VLn.

The range of $\mathrm{NH}_{3}$ desorption temperatures for all of the catalysts are provided in Table 2 . Note that the values in $\mathrm{mV}$ presented in Table 2 for the intensity of the peaks have a direct relation to the amount of desorbed ammonia, 
Table 1. Textural properties of clays

\begin{tabular}{lccc}
\hline Clays & $\mathrm{S}_{\mathrm{BET}} /\left(\mathrm{m}^{2} \mathrm{~g}^{-1}\right)$ & Pore diameter $/ \AA$ & $\begin{array}{c}\text { Pore volume / } \\
\left(\mathrm{cm}^{3} \mathrm{~g}^{-1}\right)\end{array}$ \\
\hline BBa & 170 & 40.6 & 0.17 \\
BBn & 123 & 45.8 & 0.14 \\
VLa & 238 & 41.4 & 0.25 \\
VLn & 71 & 41.0 & 0.07 \\
\hline
\end{tabular}

and thus with the quantity of acid sites. Although it is not possible to obtain an absolute value, these results allow us to compare the relative surface acidities of the different catalysts studied here. The clays presented two peaks, one at lower temperatures (200 to $300^{\circ} \mathrm{C}$ ), related to Bronsted or weaker Lewis acid sites, and another at higher temperatures $\left(300\right.$ to $800{ }^{\circ} \mathrm{C}$ ), related to strong acid sites. The intensity of both peaks was low, leading to the conclusion that the catalysts present few acidic sites. However, it is possible to conclude that the acid treatment of BBn had not increased the acidity of the sample and that the treatment of VLn increased the weak acid sites.

Table 2. Temperature ranges and peak intensity $\left(\mathrm{NH}_{3}-\mathrm{TPD}\right)$

\begin{tabular}{lcc}
\hline Clays & Temperature ranges $/{ }^{\circ} \mathrm{C}$ & Peak intensity $/ \mathrm{mV}$ \\
\hline BBa & $200-300$ and $300-800$ & 6 and 11 \\
BBn & $200-300$ and $300-800$ & 8 and 11 \\
VLa & $200-350$ and $350-800$ & 15 and 8 \\
VLn & $200-300$ and $300-800$ & 6 and 13 \\
\hline
\end{tabular}

The thermodesorption of $n$-butylamine analysis corroborate the $\mathrm{NH}_{3}$-TPD results. The data showed that the acid treatment of VLn increased the weak acid sites but did not affect the number of moderate and strong sites. Moreover, the treatment of BBn slightly increases the weak acid sites. The number of acid sites as a function of temperature is summarized in Table 3.

Table 3. Number of acid sites ( $\mathrm{mmol} \mathrm{g}^{-1}$ clay) per range of temperature

\begin{tabular}{lccc}
\hline Clays & $50-150{ }^{\circ} \mathrm{C}$ & $150-350{ }^{\circ} \mathrm{C}$ & $350-500{ }^{\circ} \mathrm{C}$ \\
\hline BBa & 0.29 & 0.31 & 0.45 \\
BBn & 0.18 & 0.26 & 0.43 \\
VLa & 0.61 & 0.40 & 0.74 \\
VLn & 0.27 & 0.39 & 0.78 \\
\hline
\end{tabular}

The TGA and DTA profiles obtained for the different clays are indicated in Table 4 and Figure 3, respectively. The DTA of the raw material revealed an intense endothermic peak between 25 and $100{ }^{\circ} \mathrm{C}$, accompanied by a continuous loss of mass in the TGA. This peak can be attributed to the dehydration of the samples due to water molecules adsorbed in the interlayer or coordinated with exchangeable cations. The peak around $500{ }^{\circ} \mathrm{C}$ is a characteristic one and can be attributed to the loss of structural hydroxyls in iron-rich smectites. At $900{ }^{\circ} \mathrm{C}$, a soft double endoexothermic peak appeared in the natural clays. The endothermic peak represents the destruction of the crystalline framework and structural dehydration, whereas the exothermic peak represents the formation of quartz. The TGA showed that the BBa clay is more thermally stable, losing only about $1 \%$ of its mass with increasing temperature.

Table 4. Loss of mass from the TGA curves

\begin{tabular}{lcccc}
\hline \multirow{2}{*}{$\begin{array}{l}\text { Temperature } \\
\text { ranges } /{ }^{\circ} \mathrm{C}\end{array}$} & $\mathrm{BBn}$ & $\mathrm{BBa}$ & $\mathrm{VLn}$ & $\mathrm{VLa}$ \\
\cline { 2 - 5 } $25-100$ & $4.5 \%$ & $1.0 \%$ & $5.0 \%$ & $4.5 \%$ \\
$100-600$ & $3.5 \%$ & - & $7.5 \%$ & $3.5 \%$ \\
$600-1000$ & $1.5 \%$ & - & $1.0 \%$ & $1.0 \%$ \\
\hline
\end{tabular}

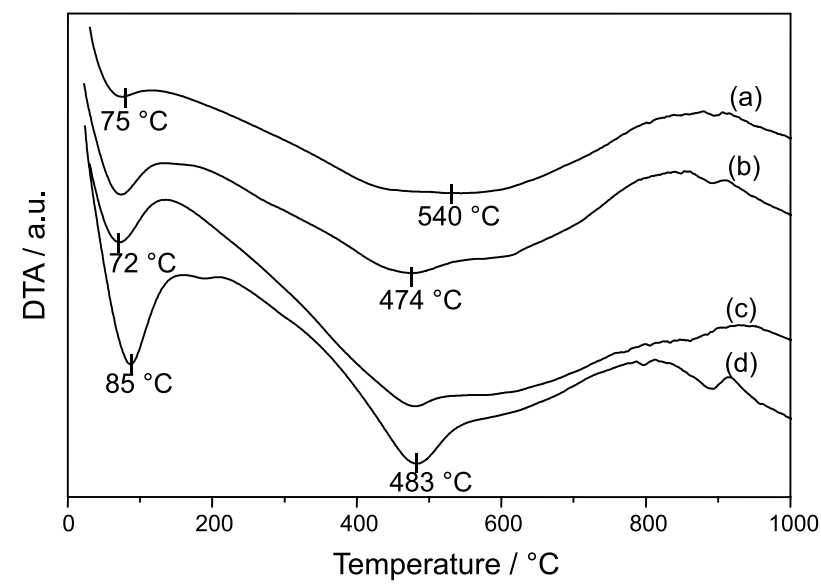

Figure 3. Differential thermal analysis (DTA) curves of clays: (a) BBa, (b) BBn, (c) VLa, (d) VLn.

The IR spectra of the clays are indicated in Figure 4. A strong band at $900-1300 \mathrm{~cm}^{-1}$ was assigned to asymmetric stretching of $\mathrm{Si}-\mathrm{O}$ and $\mathrm{Al}-\mathrm{O}$. For BBn was observed an absorption band at $790 \mathrm{~cm}^{-1}$ related to the $\mathrm{SiO}_{4}$ vibrations of non-structural silicates, which disappeared after the acid treatment. The most remarkable similarity between the natural clay spectra and those of the acid-activated clays were bands between 3700 and $3200 \mathrm{~cm}^{-1}$, which can be related to structural $\mathrm{OH}^{-}$in kaolinite (bands from 3700 and $3600 \mathrm{~cm}^{-1}$ ), to free hydroxyl mode vibrations (at $3630 \mathrm{~cm}^{-1}$ ), and to hydroxyl hydrogen bond at $3420 \mathrm{~cm}^{-1}$, and the vibrations of associated hydroxyl groups at $1640 \mathrm{~cm}^{-1}$. 


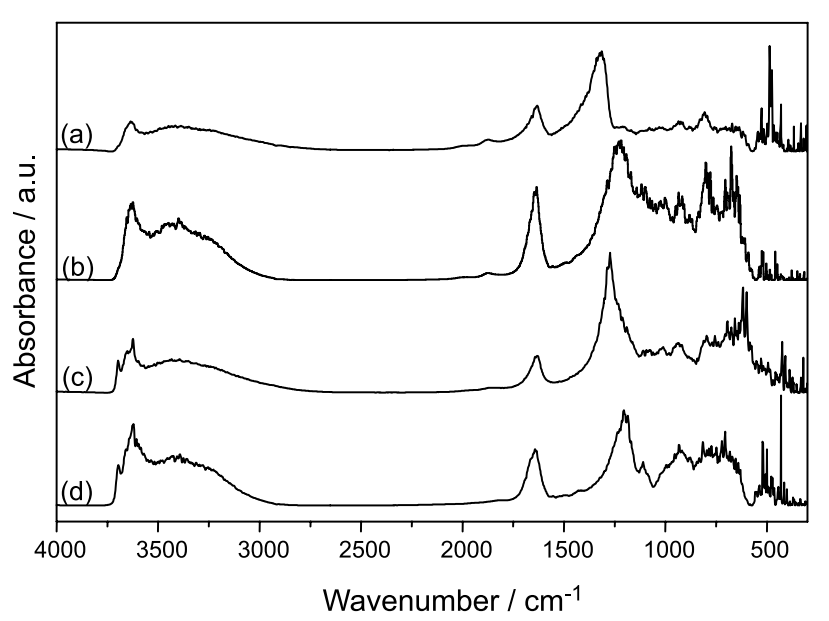

Figure 4. Infrared spectra of the studied clays: (a) BBa, (b) BBn, (c) VLa, (d) VLn.

\section{Catalysts performance in esterification}

The catalytic performance of BBn, VLn, BBa and VLa was investigated in the esterification of several carboxylic acids with different alcohols. The purpose was to evaluate the versatility of the acid-activated clays as catalysts in the synthesis of esters from carboxylic acids and alcohols with different chemical structures. The montmorillonite K10, a commercial catalyst produced by the acid treatment of raw clay, ${ }^{32}$ was also used. The reactions were performed at atmospheric pressure, and neither a Dean-Stark apparatus nor a co-solvent was used. The duplicates presented a difference from 0.5 to $4 \%$ of conversion. The average results are summarised in Table 5.

The acid activation treatment markedly increased the catalytic activities of the clays. The conversion of lauric, cyclohexanoic and phenylacetic acids to their methyl esters was higher using $\mathrm{BBa}$ or VLa than with BBn or VLn. BBa and VLa also exhibited better results than did the commercial clay K10. Benzoic acid underwent no conversion under similar conditions. The selectivity of the esterification of aliphatic carboxylic acid using $\mathrm{Fe}^{3+}-\mathrm{K}-10$ montmorillonite has been demonstrated by Srinivas and Das. ${ }^{23}$

With the exception of the esterification of phenylacetic acid (wherein the two catalysts promoted the same conversion, $c a .90 \%$ ), VLa presented slightly higher conversions to methyl esters than did BBa. These values can be attributed to the greater specific area and pore volume of the VLa catalyst. Both the natural and activated clays promoted the esterification of phenylacetic acid with methanol more efficiently than those of other carboxylic acids. This result may be associated with the presence of methylene in the phenylacetic acid structure, allowing the carboxyl group to rotate. This rotation increases the probability of access to the catalytic site in the clay.

The acid activation allows the esterification of phenylacetic acid with hexanol and cyclohexanol at high conversion rates. The reactions with these alcohols were carried out without cooled water circulation in the reflux condenser, which can help evaporate the water produced by the reaction. Even so, the results indicated a slightly reduced conversion to esters. This observation can be attributed mainly to steric effects.

BBn provided a slightly better conversion rate in the synthesis of methyl phenylacetate and hexyl phenylacetate than did VLn. This result is consistent with the characterisation data, which indicated that the latter has a lower specific area and less pore volume. After the acid treatment, VLa presented higher specific area and more pore volume than $\mathrm{BBa}$. This difference between the textural properties of the two acid-activated clays could explain the higher conversion

Table 5. Esterification of different carboxylic acids with various alcohols

\begin{tabular}{|c|c|c|c|c|c|c|c|}
\hline \multirow{2}{*}{ entry } & \multirow{2}{*}{ Carboxylic acid } & \multirow{2}{*}{ Alcohol } & \multicolumn{5}{|c|}{ Conversion / \% } \\
\hline & & & $\mathrm{BBn}$ & $\mathrm{BBa}$ & VLn & $\mathrm{VLa}$ & $\mathrm{K} 10$ \\
\hline 1 & lauric acid & methanol & 4 & 84 & 2 & 87 & 74 \\
\hline 2 & cyclohexanoic acid & methanol & 3 & 70 & 11 & 82 & 24 \\
\hline 3 & phenylacetic acid & methanol & 39 & 91 & 22 & 90 & 86 \\
\hline 4 & benzoic acid & methanol & $<1$ & $<1$ & $<1$ & $<1$ & $<1$ \\
\hline 5 & lauric acid & hexanol & 31 & 89 & 36 & 84 & 47 \\
\hline 6 & cyclohexanoic acid & hexanol & 23 & 38 & 21 & 33 & 31 \\
\hline 7 & phenylacetic acid & hexanol & 38 & 75 & 28 & 82 & 83 \\
\hline 8 & benzoic acid & hexanol & $<1$ & 6 & 2 & 6 & 3 \\
\hline 9 & lauric acid & cyclohexanol & 1 & 11 & 5 & 93 & 16 \\
\hline 10 & cyclohexanoic acid & cyclohexanol & 9 & 48 & 4 & 76 & 8 \\
\hline 11 & phenylacetic acid & cyclohexanol & 8 & 23 & 29 & 76 & 11 \\
\hline 12 & benzoic acid & cyclohexanol & $<1$ & 3 & $<1$ & 4 & $<1$ \\
\hline
\end{tabular}

BBn and VLn: natural clays; BBa and VLa: acid-activated clays; K10: commercial clay. 
achieved by VLa because the $\mathrm{NH}_{3}$-TPD analyses and the thermodesorption of $n$-butylamine results did not indicate a substantial difference in acidity between these catalysts.

As with the esterifications with methanol, hexyl benzoate and cyclohexyl benzoate were obtained in limited quantities, even when using the acid-activated clays.

The natural clays performed better in the formation of hexyl esters than cyclohexyl esters. The low conversion rates for cyclohexyl esters could be attributed to steric effects induced by the catalyst. Relative to primary alcohols, it is more difficult for a secondary cyclic alcohol to access the mesoporous system of a smectite.

$\mathrm{BBa}$ and VLa were very active for the esterification of lauric acid with hexanol (89\% and $84 \%)$ and for that of phenylacetic acid with the same alcohol (75\% and $82 \%)$. In the esterification of cyclohexanoic acid with hexanol, the acid-activated clays afforded conversions close to those of the natural clays. This result could be attributed to sterically hindered access of hexanol to the electrophilic site of cyclohexanoic acid.

The esterification of carboxylic acids with cyclohexanol was catalysed more efficiently by BBa and VLa than by BBn or VLn. Moreover, the VLa catalyst provided better conversions of cyclohexyl esters than did BBa. The VLa provided better catalytic performance than did K10 for all of the esterifications assessed in this study.

It was not done a mechanistic study on the esterification using the clays as catalysts. However, we assume that the mechanism involved is probably similar those proposed by our group in other works involving Bronsted or Lewis acid transesterification, esterification or hydrolysis. ${ }^{5,6,8,9,33}$

\section{Conclusions}

Two Brazilian clays mainly composed by smectite were acid activated without any previous treatment. The acid treatment significantly increased the surface area of the materials without changing their surface acidity. The catalytic activity of the clays for esterification was strongly enhanced after acid treatment. The acid-activated clays exhibited high efficiency even when the by-product (water) was not removed. These catalysts show potential use as catalyst for the esterification of multiple carboxylic acids with various alcohols, mainly because smectite is cheap and abundant in Brazil.

\section{Supplementary Information}

Supplementary information (Figures S1-S16, Table S1-S2) is available free of charge at http://jbcs.sbq.org.br as a PDF file.

\section{Acknowledgments}

The authors thank CAPES and CNPq (Brazil) for financial support and research fellowships. The authors also wish to thank Bentonisa-Bentonita do Nordeste S.A. for providing the natural clay samples.

\section{References}

1. Yadav, G. D.; Rahuman, M. S. M. M.; Org. Process Res. Dev. 2002, 6, 706.

2. Bondioli, P.; Top. Catal. 2004, 27, 77.

3. Alvaro, M.; Corma, A.; Das, D.; Fornés, V.; García, H.; J. Catal. 2005, 231, 48 .

4. Mbaraka, I. K.; Shanks, B. H.; J. Catal. 2005, 229, 365.

5. Brandão, R. F.; Quirino, R. L.; Mello, V. M.; Tavares, A. P.; Peres, A. C.; Guinhos, F.; Rubim, J. C.; Suarez, P. A. Z.; J. Braz. Chem. Soc. 2009, 20, 954.

6. Mello, V. M.; Pousa, G. P. A. G.; Pereira, M. S. C.; Dias, I. M.; Suarez, P. A. Z.; Fuel Process. Technol. 2010, 92, 53.

7. Furuta, S.; Matsuhashi, H.; Arata, K.; Catal. Commun. 2004, 5,721 .

8. Neto, B. A. D.; Alves, M. B.; Lapis, A. A. M.; Nachtigall, F. M.; Eberlin, M. N.; Dupont, J.; Suarez, P. A. Z.; J. Catal. 2007, 249, 154.

9. Brito, Y. C.; Mello, V. M.; Macedo, C. C. S.; Meneghetti, M. R.; Suarez, P. A. Z.; Meneghetti, S. M. P.; Appl. Catal., A 2008, $351,24$.

10. Vaccari, A.; Appl. Clay Sci. 1999, 14, 161.

11. Varma, R. S.; Tetrahedron 2002, 58, 1235.

12. Cornélis, A.; Gerstmans, A.; Laszlo, P.; Mathy, A.; Zieba, I.; Catal. Lett. 1990, 6, 103.

13. Laszlo, P.; Montaufier, M. T.; Randriamahefa, S. L.; Tetrahedron Lett. 1990, 31, 4867.

14. Choudary, B. M.; Rao, B. P. C.; Chowdari, N. S.; Kantam, M. L.; Catal. Commun. 2002, 3, 363.

15. Kou, M. R. S.; Mendioroz, S.; Salerno, P.; Muñoz, V.; Appl. Catal., A. 2002, 6337, 1.

16. Varma, R. S.; Dahiya, R.; Tetrahedron Lett. 1997, 38, 2043.

17. Ribeiro, N. M.; Pinto, A. C.; Violante, F. A.; Dias, M. O.; Silva, B. V.; Catal. Commun. 2007, 8, 2130.

18. Collet, C.; Laszlo, P.; Tetrahedron Lett. 1991, 32, 2905.

19. Ponde, D.; Borate, H. B.; Sudalai, A.; Ravindranathan, T.; Deshpande, V. H.; Tetrahedron Lett. 1996, 37, 4605.

20. Lei, Z.; Zhang, Q.; Luo, J.; He, X.; Tetrahedron Lett. 2005, 46, 3505.

21. Silva, F. C.; Souza, M. C. B. V.; Ferreira, V. F.; Sabino, S. J.; Antunes, O. A. C.; Catal. Commun. 2004, 5, 151.

22. Kantam, M. L.; Bhaskar, V.; Choudary, B. M.; Catal. Lett. 2002, $78,185$.

23. Srinivas, K. V. N. S.; Das, B.; J. Org. Chem. 2003, 68, 1165. 
24. Kawabata, T.; Mizugaki, T.; Ebitani, K.; Kaneda, K.; Tetrahedron Lett. 2003, 44, 9205.

25. Reddy, C. R.; Vijayakumar, B.; Iyengar, P.; Nagendrappa, G.; Prakash, B. S. J.; J. Mol. Catal. A: Chem. 2004, 223, 117.

26. Reddy, C. R.; Iyengar, P.; Nagendrappa, G.; Prakash, B. S. J.; Catal. Lett. 2005, 101, 87.

27. Neji, S. B.; Trabelsi, M.; Frikha, M. H.; Energies 2009, $2,1107$.

28. Bhorodwaj, S. K.; Dutta, D. K.; Appl. Catal., A 2010, 378, 221.

29. Foletto, E. L.; Volzone, C.; Morgado, A. F.; Porto, L. M.; Ceramica 2001, 47, 208.

30. Pinto, A. C.; Oliveira, C. H.; Ribeiro, N. M.; Quim. Nova 2008, $31,562$.
31. Faria, R. C. M.; Rezende, M. J. C.; Rezende, C. M.; Pinto, A. C.; Quim. Nova 2007, 30, 1900.

32. Flessner, U.; Jones, D. J.; Rozière, J.; Zajac, J.; Storaro, L.; Lenarda, M.; Pavan, M.; Jiménez-López, A.; RodríguezCastellón, E.; Trombetta, M.; Busca, G; J. Mol. Catal. A: Chem. 2001, 168, 247.

33. Alves, M. B.; Medeiros, F. C. M.; Suarez, P. A. Z.; Ind. Eng. Chem. Res. 2010, 49, 7176.

Submitted: July 28, 2011

Published online: May 8, 2012 


\section{Preparation, Characterisation and Evaluation of Brazilian Clay-Based Catalysts for use in Esterification Reactions}

Michelle J. C. Rezende, ${ }^{*, a}$ Mírian S. C. Pereira, ${ }^{b}$ Gabriel F. N. Santos, ${ }^{b}$ Gabriel O. P. Aroeira, ${ }^{a}$ Tiago C. Albuquerque Jr., ${ }^{a}$ Paulo A. Z. Suarez ${ }^{b}$ and Angelo C. Pinto ${ }^{a}$

anstituto de Química, Universidade Federal do Rio de Janeiro, Cidade Universitária, CT, Bloco A, 21941-909 Rio de Janeiro-RJ, Brazil

${ }^{b}$ Instituto de Química, Universidade de Brasília, Campus Universitário Darcy Ribeiro, CP 4478, 70904-970 Brasília-DF, Brazil

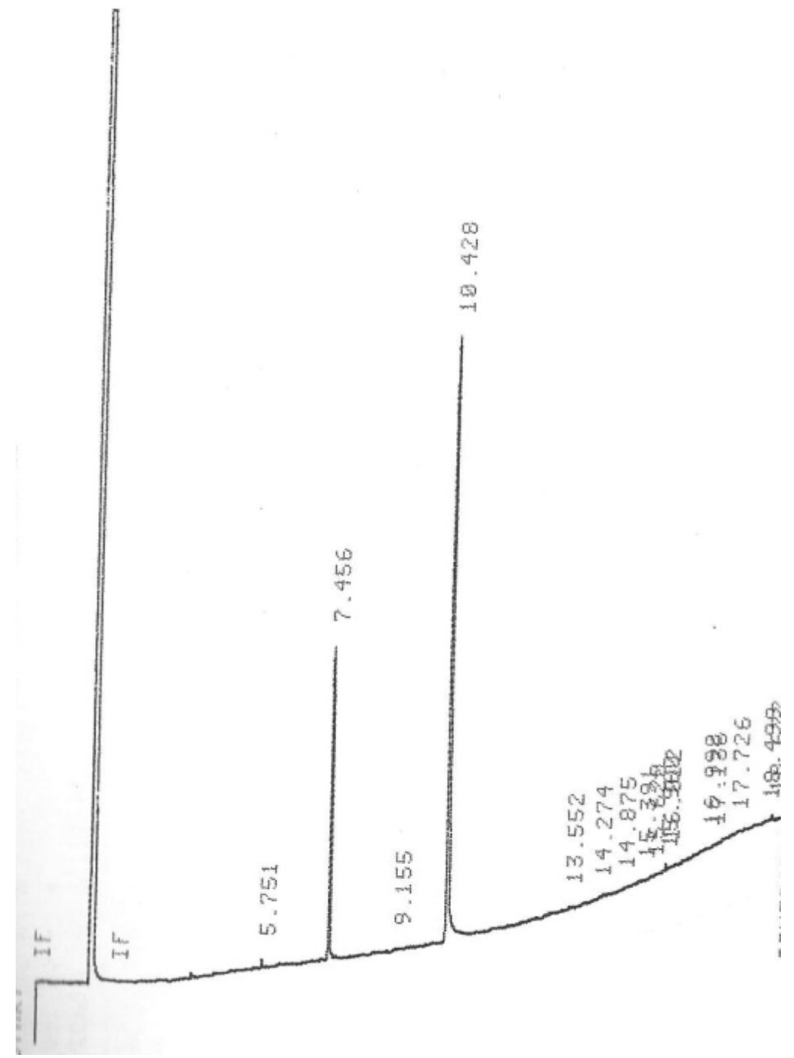

Figure S1. Chromatogram of lauric acid $\left(t_{R} 10.4 \mathrm{~min}\right)$ and internal standard $\left(\mathrm{t}_{\mathrm{R}} 7.5 \mathrm{~min}\right)$.

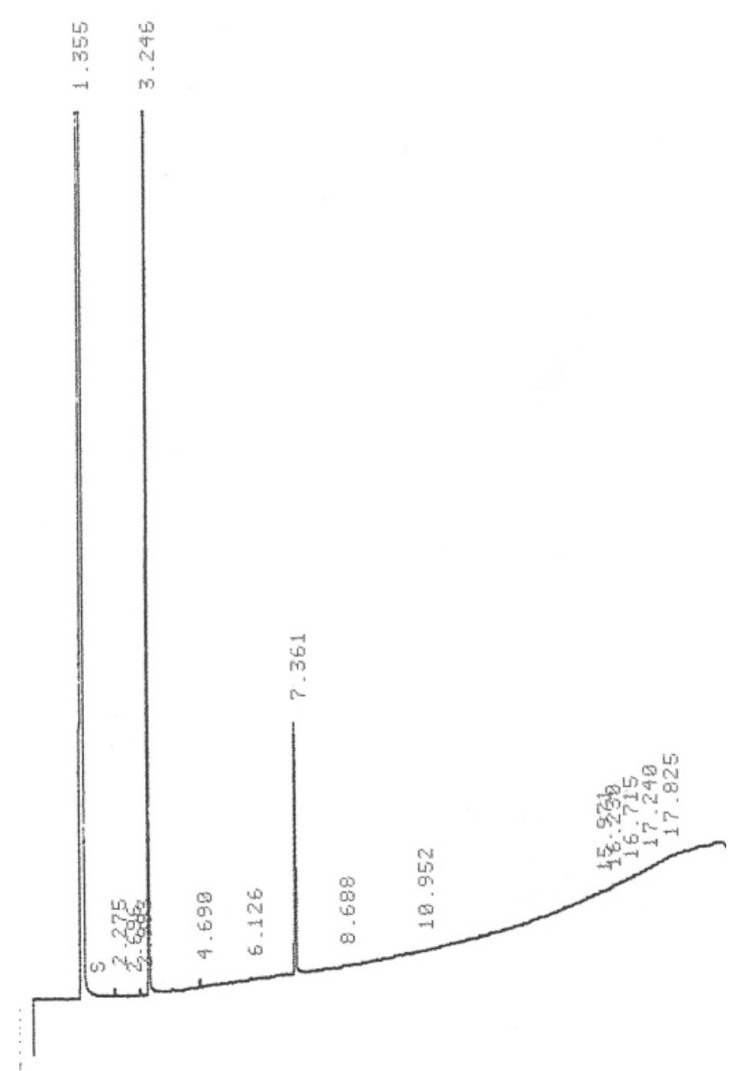

Figure S2. Chromatogram of methyl laurate $\left(t_{R} 3.2 \mathrm{~min}\right)$ and internal standard $\left(\mathrm{t}_{\mathrm{R}} 7.4 \mathrm{~min}\right)$. 


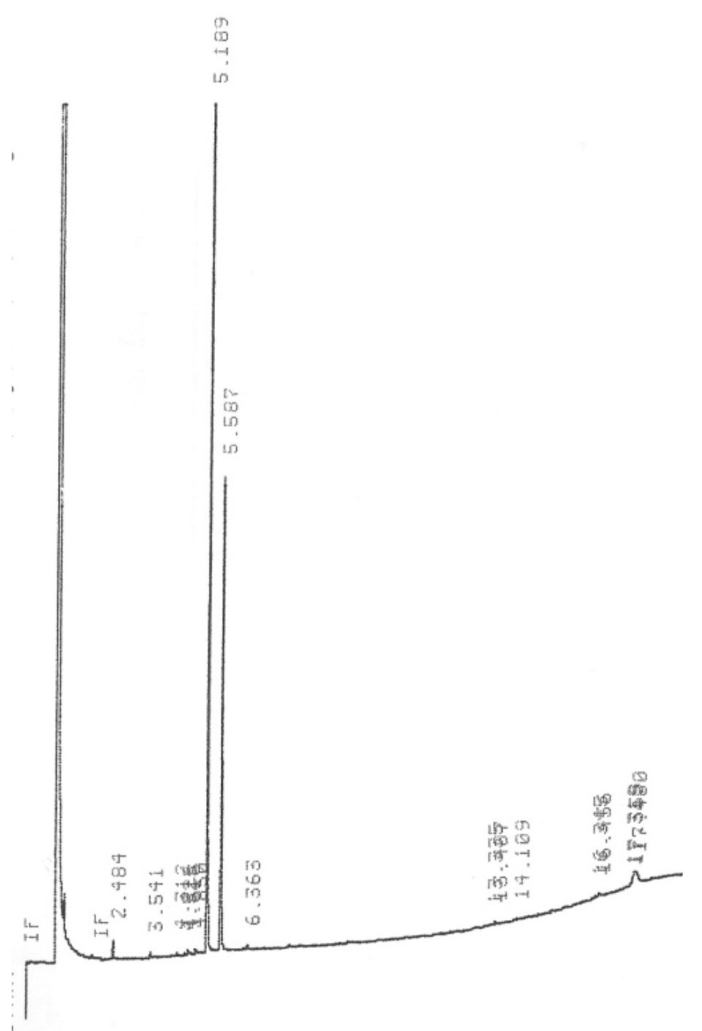

Figure S3. Chromatogram of hexyl laurate $\left(t_{R} 5.2 \mathrm{~min}\right)$ and internal standard $\left(\mathrm{t}_{\mathrm{R}} 5.6 \mathrm{~min}\right)$.

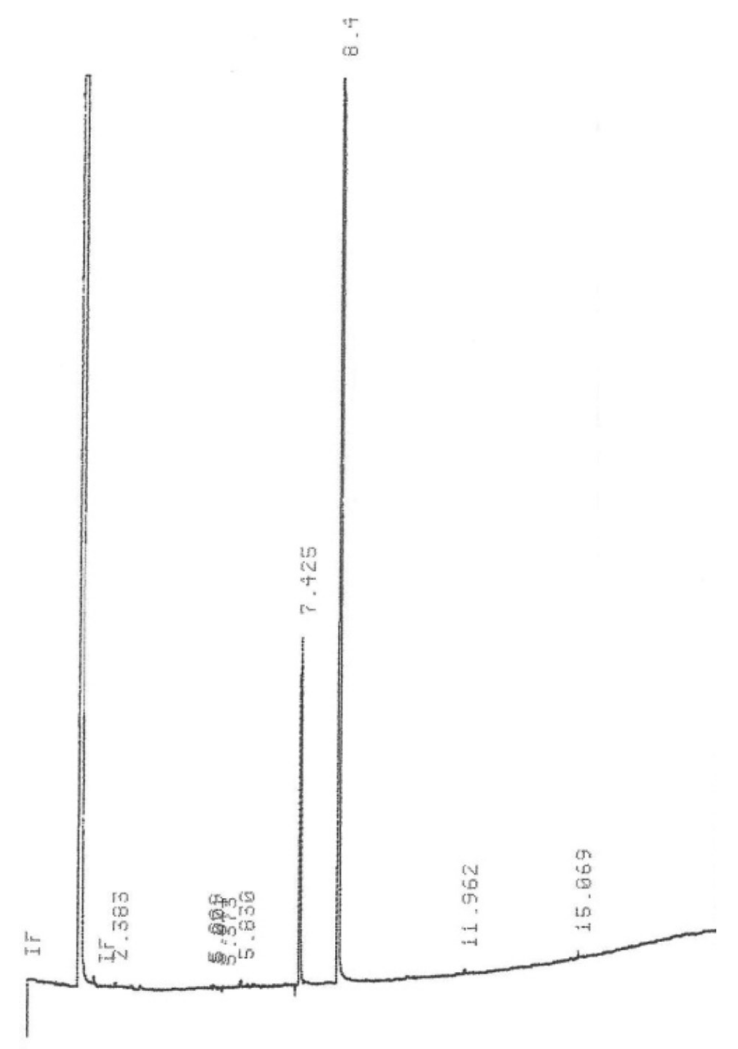

Figure S4. Chromatogram of cyclohexyl laurate $\left(t_{R} 8.4 \mathrm{~min}\right)$ and internal standard $\left(\mathrm{t}_{\mathrm{R}} 7.4 \mathrm{~min}\right)$

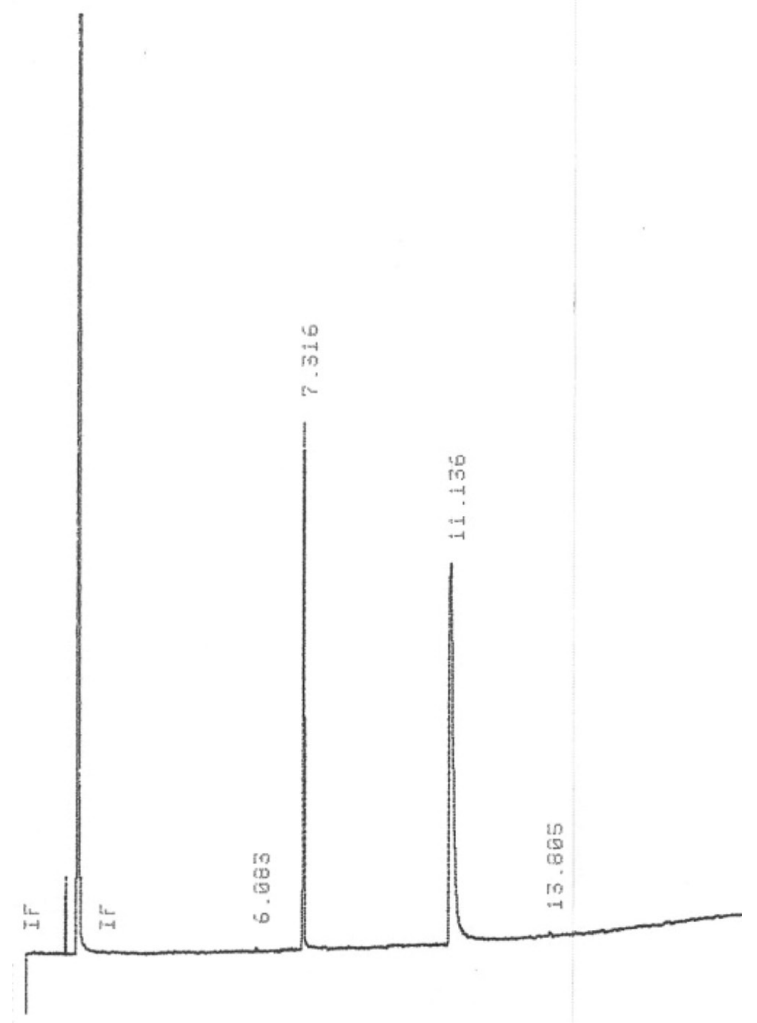

Figure S5. Chromatogram of phenylacetic acid $\left(t_{R} 11.1 \mathrm{~min}\right)$ and internal standard $\left(\mathrm{t}_{\mathrm{R}} 7.3 \mathrm{~min}\right)$.

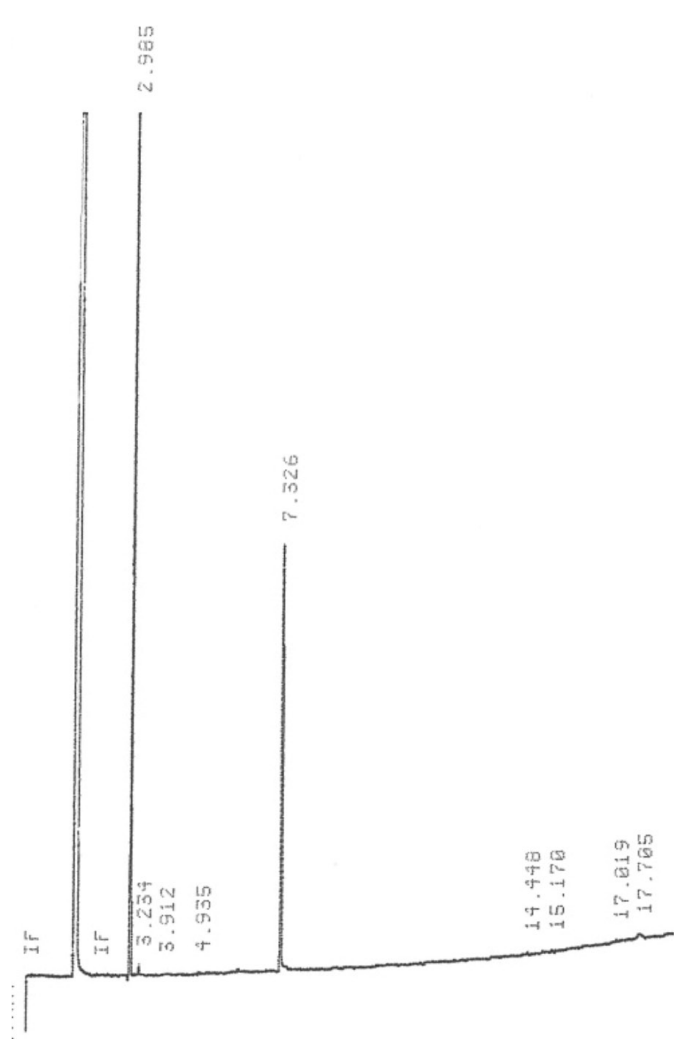

Figure S6. Chromatogram of methyl phenylacetate $\left(t_{R} 3.0 \mathrm{~min}\right)$ and internal standard ( $\left.\mathrm{t}_{\mathrm{R}} 7.3 \mathrm{~min}\right)$. 


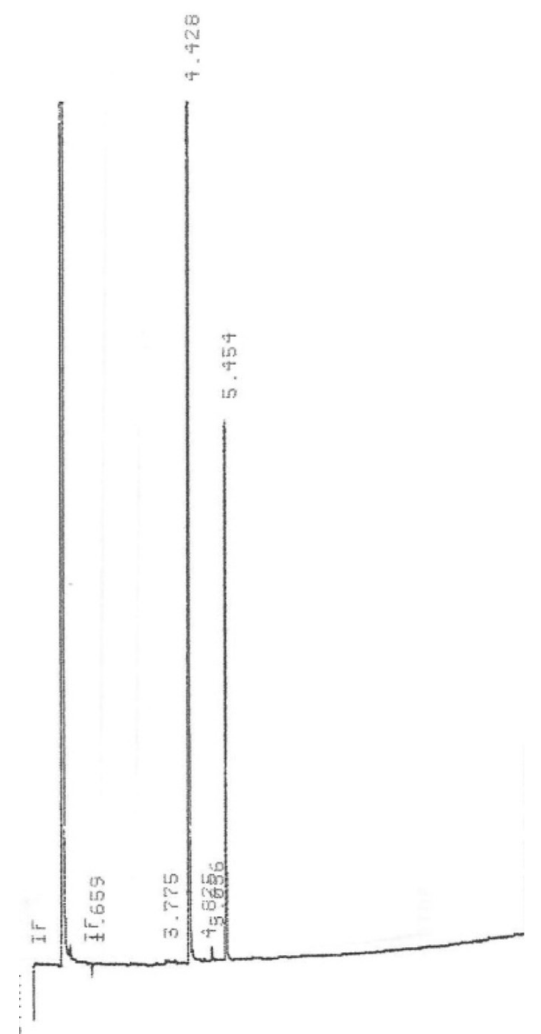

Figure S7. Chromatogram of hexyl phenylacetate $\left(t_{R} 4.4 \mathrm{~min}\right)$ and internal standard $\left(\mathrm{t}_{\mathrm{R}} 5.4 \mathrm{~min}\right)$.

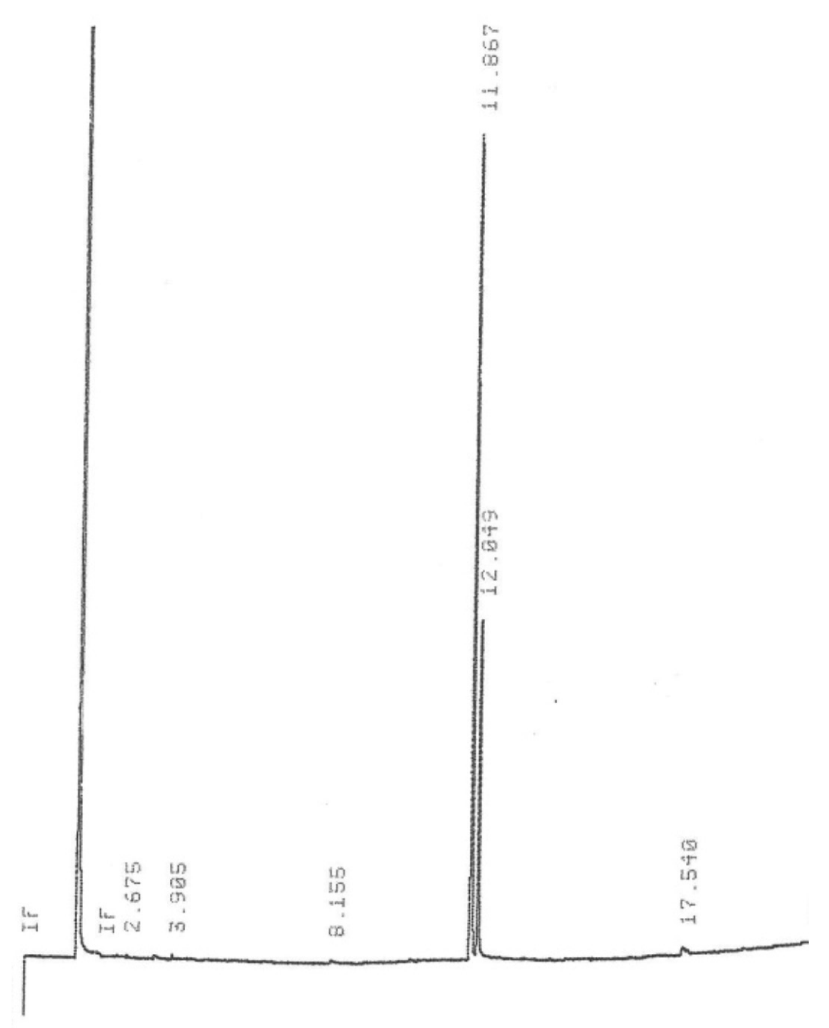

Figure S8. Chromatogram of cyclohexyl phenylacetate $\left(t_{R} 11.9 \mathrm{~min}\right)$ and internal standard $\left(t_{R} 12.0 \mathrm{~min}\right)$.

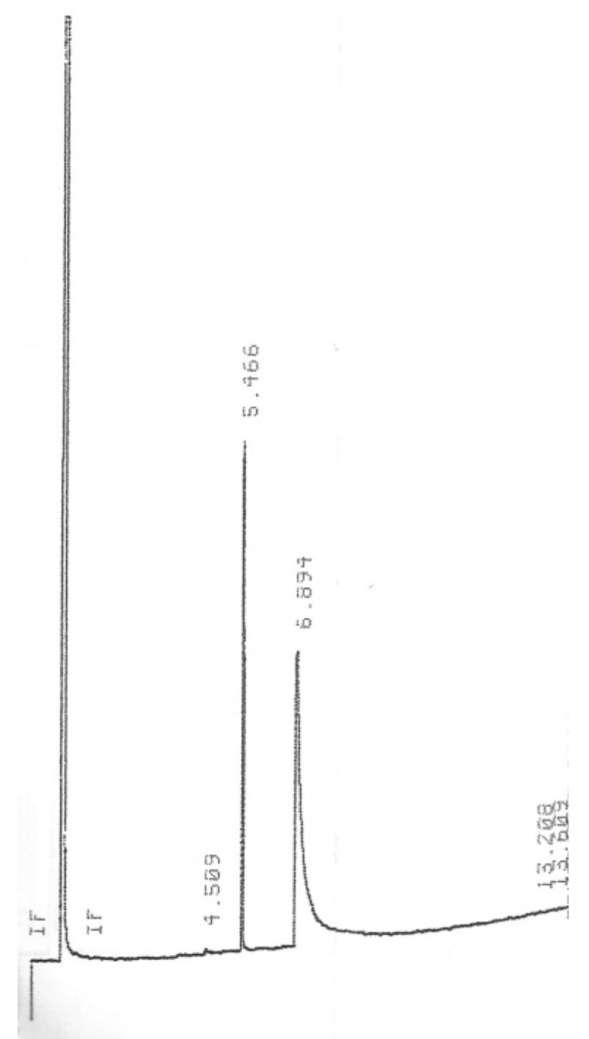

Figure S9. Chromatogram of benzoic acid $\left(t_{R} 6.9 \mathrm{~min}\right)$ and internal standard $\left(\mathrm{t}_{\mathrm{R}} 5.5 \mathrm{~min}\right)$.

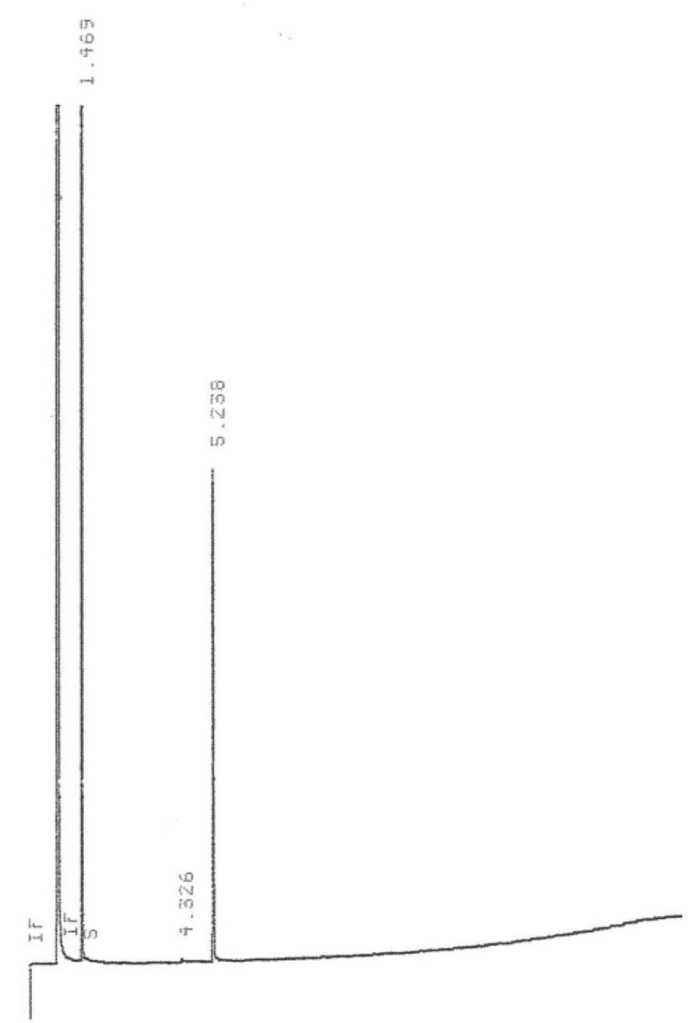

Figure S10. Chromatogram of methyl benzoate $\left(t_{R} 1.5 \mathrm{~min}\right)$ and internal standard $\left(\mathrm{t}_{\mathrm{R}} 5.2 \mathrm{~min}\right)$. 


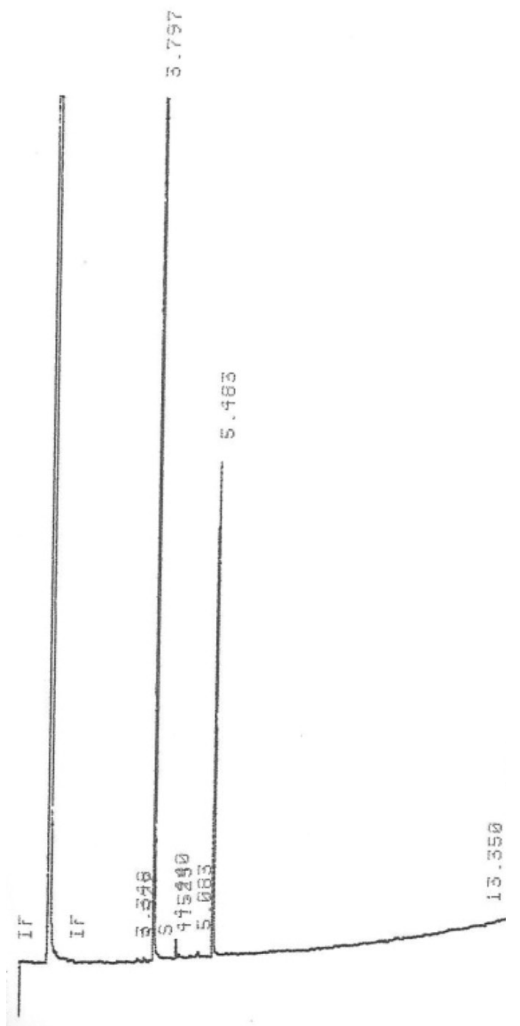

Figure S11. Chromatogram of hexyl benzoate $\left(t_{R} 3.8 \mathrm{~min}\right)$ and internal standard $\left(\mathrm{t}_{\mathrm{R}} 5.5 \mathrm{~min}\right)$.

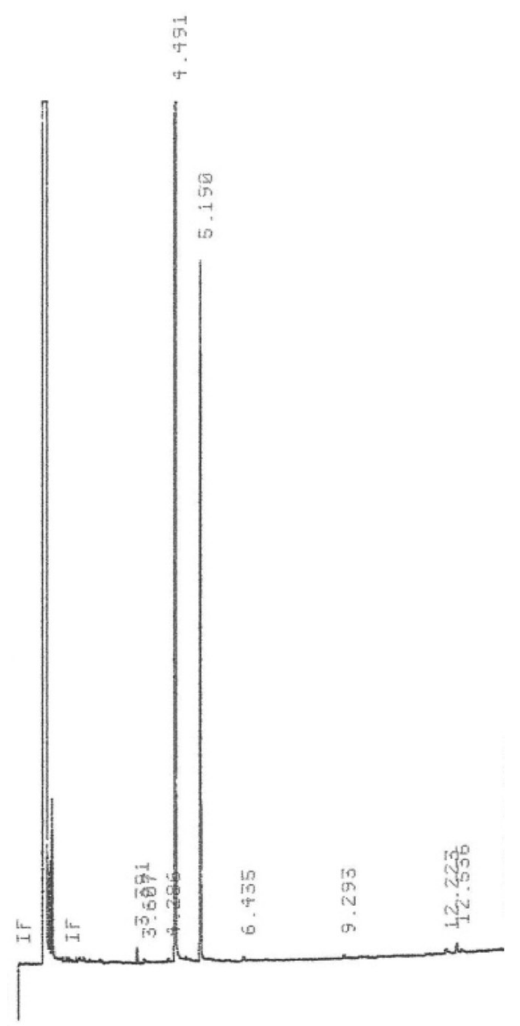

Figure S12. Chromatogram of cyclohexyl benzoate $\left(t_{R} 4.5 \mathrm{~min}\right)$ and internal standard ( $\left.\mathrm{t}_{\mathrm{R}} 5.2 \mathrm{~min}\right)$.

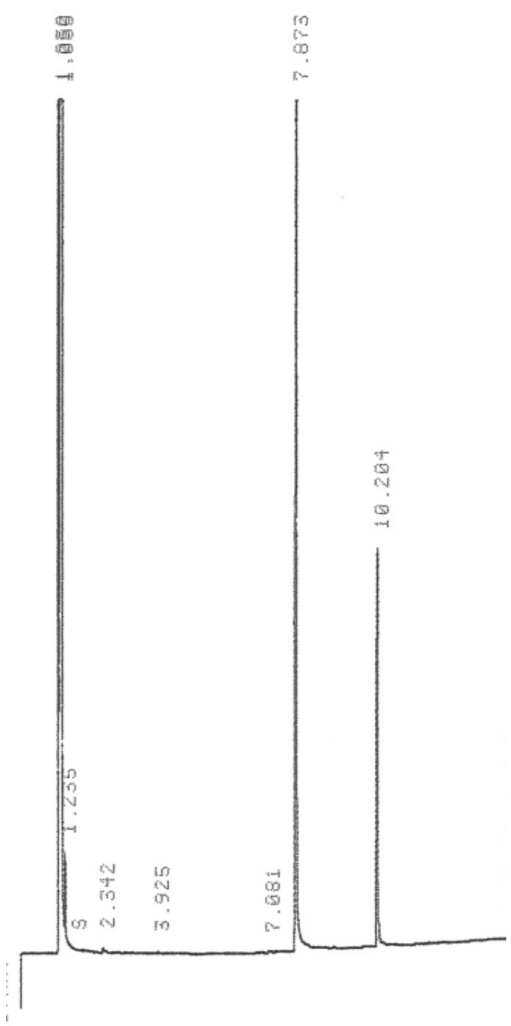

Figure S13. Chromatogram of cyclohexanoic acid $\left(t_{R} 7.9 \mathrm{~min}\right)$ and internal standard ( $\left.\mathrm{t}_{\mathrm{R}} 10.2 \mathrm{~min}\right)$.

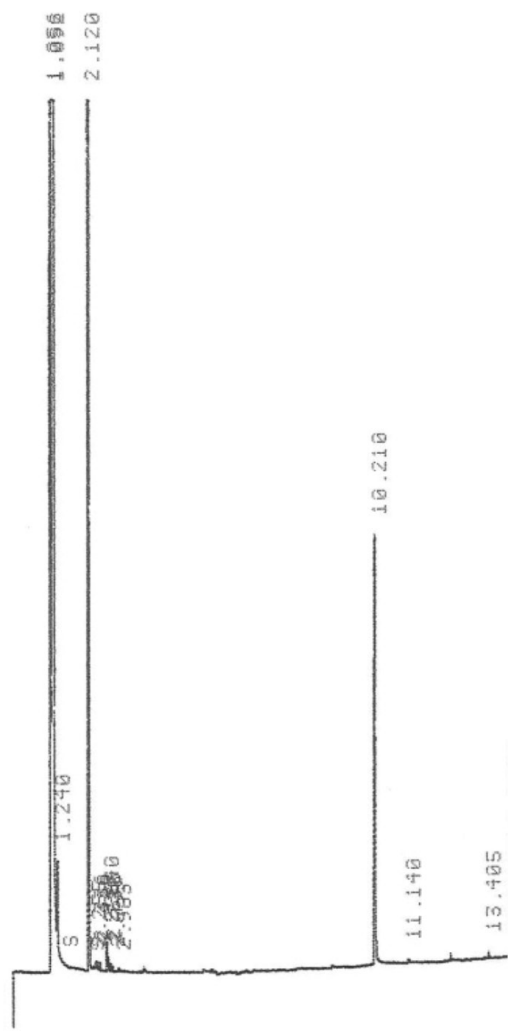

Figure S14. Chromatogram of methyl cyclohexanoate $\left(t_{R} 2.1 \mathrm{~min}\right)$ and internal standard ( $\left.t_{\mathrm{R}} 10.2 \mathrm{~min}\right)$. 


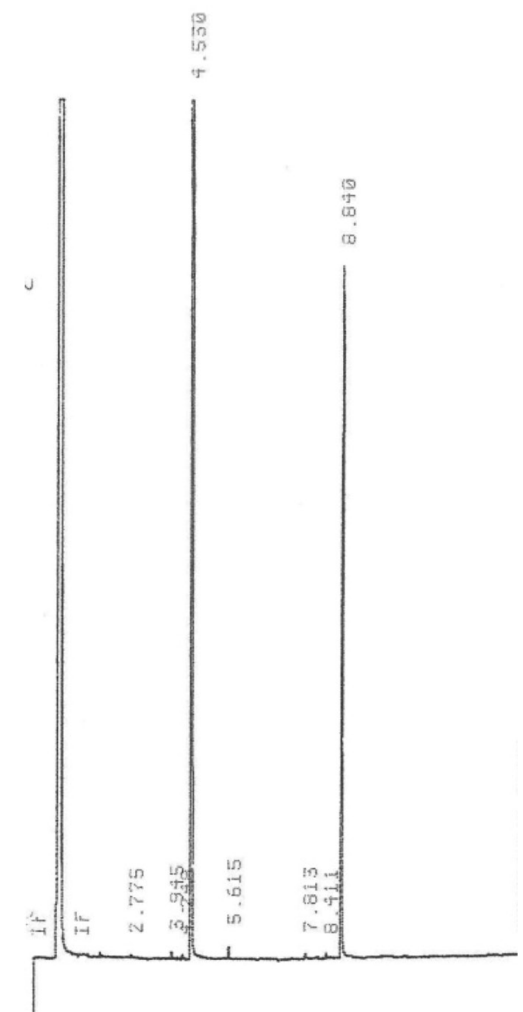

Figure S15. Chromatogram of hexyl cyclohexanoate $\left(t_{R} 4.5 \mathrm{~min}\right)$ and internal standard ( $\left.\mathrm{t}_{\mathrm{R}} 8.8 \mathrm{~min}\right)$.

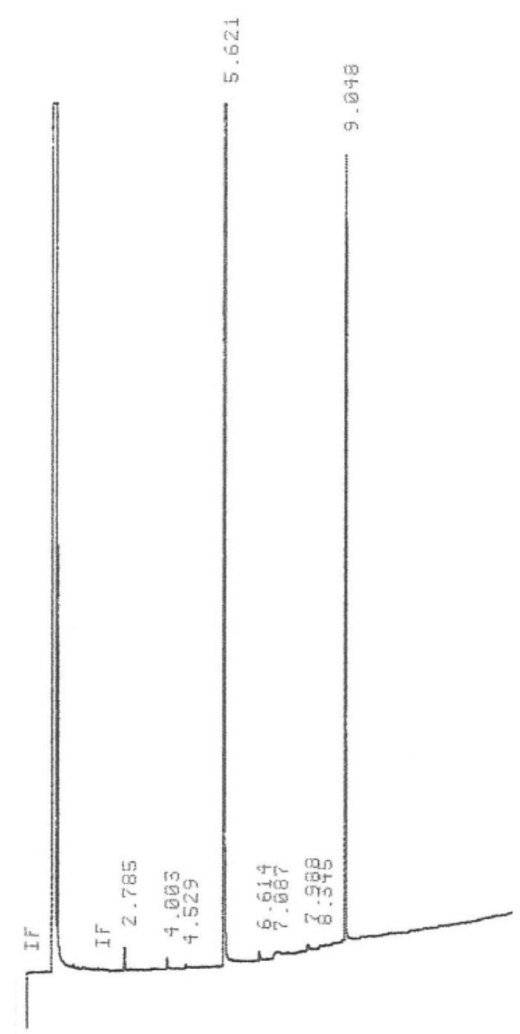

Figure S16. Chromatogram of cyclohexyl cyclohexanoate ( $\left.t_{R} 5.6 \mathrm{~min}\right)$ and internal standard $\left(\mathrm{t}_{\mathrm{R}} 9.0 \mathrm{~min}\right)$. 
Table S1. Data for calculation of the response factors of acids and esters standards

\begin{tabular}{|c|c|c|c|c|c|c|}
\hline Standard & $\mathrm{S}_{\text {Area }}$ & $\mathrm{S}_{\mathrm{Conc}}$ & $\mathrm{IS}_{\text {Area }}$ & $\mathrm{IS}_{\mathrm{Conc}}$ & $\mathrm{F}_{\mathrm{R}}$ & $\mathrm{F}_{\mathrm{R}}$ \\
\hline lauric acid & 218841 & 1020 & 83333 & 268 & 0.690 & 0.684 \\
\hline lauric acid & 216720 & 1020 & 83928 & 268 & 0.678 & \\
\hline methyl laurate & 492794 & 1040 & 71675 & 268 & 1.772 & 1.758 \\
\hline methyl laurate & 539675 & 1040 & 79744 & 268 & 1.744 & \\
\hline cyclohexyl laurate & 412109 & 1630 & 77671 & 268 & 0.872 & 0.876 \\
\hline cyclohexyl laurate & 506955 & 1630 & 94774 & 268 & 0.879 & \\
\hline hexyl laurate & 323411 & 1330 & 107778 & 238.5 & 0.538 & 0.534 \\
\hline hexyl laurate & 368092 & 1330 & 124750 & 238.5 & 0.529 & \\
\hline phenylacetic acid & 384842 & 1620 & 136902 & 248 & 0.430 & 0.421 \\
\hline phenylacetic acid & 378276 & 1620 & 140893 & 248 & 0.411 & \\
\hline methyl phenylacetate & 438196 & 1410 & 156421 & 248 & 0.493 & 0.509 \\
\hline methyl phenylacetate & 366980 & 1410 & 122895 & 248 & 0.525 & \\
\hline cyclohexyl phenylacetate & 1366540 & 1710 & 144943 & 248 & 1.367 & 1.375 \\
\hline cyclohexyl phenylacetate & 1394862 & 1710 & 146311 & 248 & 1.383 & \\
\hline hexyl phenylacetate & 904087 & 1670 & 122677 & 239 & 1.055 & 1.054 \\
\hline hexyl phenylacetate & 927589 & 1670 & 126073 & 239 & 1.053 & \\
\hline cyclohexanoic acid & 412674 & 1340 & 108036 & 265.5 & 0.757 & 0.727 \\
\hline cyclohexanoic acid & 372292 & 1340 & 105803 & 265.5 & 0.697 & \\
\hline methyl cyclohexanoate & 728707 & 1940 & 112690 & 265.5 & 0.885 & 0.913 \\
\hline methyl cyclohexanoate & 596780 & 1940 & 86712 & 265.5 & 0.942 & \\
\hline cyclohexyl cyclohexanoate & 891191 & 1630 & 159304 & 238.5 & 0.818 & 0.827 \\
\hline cyclohexyl cyclohexanoate & 1070347 & 1630 & 187300 & 238.5 & 0.836 & \\
\hline hexyl cyclohexanoate & 2038730 & 2870 & 167994 & 241 & 1.019 & 1.021 \\
\hline hexyl cyclohexanoate & 1993908 & 2870 & 163741 & 241 & 1.022 & \\
\hline benzoic acid & 262536 & 960 & 98661 & 265.5 & 0.736 & 0.756 \\
\hline benzoic acid & 249880 & 960 & 89095 & 265.5 & 0.776 & \\
\hline methyl benzoate & 263392 & 940 & 92042 & 265.5 & 0.808 & 0.806 \\
\hline methyl benzoate & 279626 & 940 & 98359 & 265.5 & 0.803 & \\
\hline cyclohexyl benzoate & 640039 & 1850 & 104871 & 238.5 & 0.787 & 0.785 \\
\hline cyclohexyl benzoate & 568059 & 1850 & 93466 & 238.5 & 0.783 & \\
\hline hexyl benzoate & 874892 & 1630 & 116861 & 239 & 1.098 & 1.101 \\
\hline hexyl benzoate & 863688 & 1630 & 114751 & 239 & 1.104 & \\
\hline
\end{tabular}

$\mathrm{S}_{\text {Area }}=$ standard area; $\mathrm{S}_{\mathrm{Conc}}=$ standard concentration at $\mathrm{mg} \mathrm{L}^{-1} ; \mathrm{IS}_{\mathrm{Area}}=$ internal standard area; $\mathrm{IS}_{\mathrm{Conc}}=$ internal standard concentration at mg $\mathrm{L}^{-1} ; \mathrm{F}_{\mathrm{R}}=$ response factor; $\mathrm{F}_{\mathrm{R}}=\left(\mathrm{S}_{\text {Area }} / \mathrm{S}_{\text {Conc }}\right) /\left(\mathrm{IS}_{\text {Area }} / \mathrm{IS}_{\text {Conc }}\right)$. 
Table S2. Oven temperature program used on GC-FID analyses

\begin{tabular}{|c|c|c|c|c|}
\hline \multirow{2}{*}{ Product } & \multirow{2}{*}{ Oven temperature program } & \multicolumn{3}{|c|}{$\mathrm{tR} / \mathrm{min}$} \\
\hline & & acid & ester & IS \\
\hline methyl phenylacetate & $140{ }^{\circ} \mathrm{C}$ to $180^{\circ} \mathrm{C}$ at $10^{\circ} \mathrm{C} \mathrm{min}-1$ followed by $180{ }^{\circ} \mathrm{C}$ to $220^{\circ} \mathrm{C}$ at $3{ }^{\circ} \mathrm{C} \mathrm{min}{ }^{-1}$ & 8.7 & 3.0 & 5.4 \\
\hline hexyl phenylacetate & $140{ }^{\circ} \mathrm{C}$ to $180^{\circ} \mathrm{C}$ at $10^{\circ} \mathrm{C} \mathrm{min}-1$ followed by $180{ }^{\circ} \mathrm{C}$ to $220^{\circ} \mathrm{C}$ at $3{ }^{\circ} \mathrm{C} \mathrm{min}{ }^{-1}$ & 8.7 & 4.4 & 5.4 \\
\hline cyclohexyl phenylacetate & $\begin{array}{l}5 \mathrm{~min} \text { at } 140{ }^{\circ} \mathrm{C} \text { followed to } 180^{\circ} \mathrm{C} \text { at } 8{ }^{\circ} \mathrm{C} \mathrm{min}-1 \text {. After } 3 \mathrm{~min} \text { at } 180^{\circ} \mathrm{C} \text { followed } \\
\text { to } 220^{\circ} \mathrm{C} \text { at } 3{ }^{\circ} \mathrm{C} \text { minn-1 }^{-1}\end{array}$ & 17.6 & 11.9 & 12.0 \\
\hline methyl laurate & $140{ }^{\circ} \mathrm{C}$ to $180^{\circ} \mathrm{C}$ at $10^{\circ} \mathrm{C} \mathrm{min}-1$ followed by $180{ }^{\circ} \mathrm{C}$ to $220^{\circ} \mathrm{C}$ at $3{ }^{\circ} \mathrm{C} \mathrm{min}{ }^{-1}$ & 8.1 & 1.4 & 5.5 \\
\hline hexyl laurate & $140{ }^{\circ} \mathrm{C}$ to $180^{\circ} \mathrm{C}$ at $10^{\circ} \mathrm{C} \mathrm{min}-1$ followed by $180{ }^{\circ} \mathrm{C}$ to $220^{\circ} \mathrm{C}$ at $3{ }^{\circ} \mathrm{C} \mathrm{min}{ }^{-1}$ & 8.1 & 5.1 & 5.5 \\
\hline cyclohexyl laurate & $140{ }^{\circ} \mathrm{C}$ to $180^{\circ} \mathrm{C}$ at $10^{\circ} \mathrm{C} \mathrm{min}-1$ followed by $180{ }^{\circ} \mathrm{C}$ to $220^{\circ} \mathrm{C}$ at $3{ }^{\circ} \mathrm{C} \mathrm{min}{ }^{-1}$ & 8.1 & 8.4 & 5.5 \\
\hline methyl benzoate & $140{ }^{\circ} \mathrm{C}$ to $180^{\circ} \mathrm{C}$ at $10^{\circ} \mathrm{C} \mathrm{min}-1$ followed by $180{ }^{\circ} \mathrm{C}$ to $220^{\circ} \mathrm{C}$ at $3{ }^{\circ} \mathrm{C} \mathrm{min}{ }^{-1}$ & 6.9 & 1.5 & 5.2 \\
\hline hexyl benzoate & $140{ }^{\circ} \mathrm{C}$ to $180^{\circ} \mathrm{C}$ at $10^{\circ} \mathrm{C} \mathrm{min}-1$ followed by $180{ }^{\circ} \mathrm{C}$ to $220^{\circ} \mathrm{C}$ at $3{ }^{\circ} \mathrm{C} \mathrm{min}{ }^{-1}$ & 6.9 & 3.8 & 5.5 \\
\hline cyclohexyl benzoate & $140{ }^{\circ} \mathrm{C}$ to $180^{\circ} \mathrm{C}$ at $10^{\circ} \mathrm{C} \mathrm{min}-1$ followed by $180{ }^{\circ} \mathrm{C}$ to $220^{\circ} \mathrm{C}$ at $3{ }^{\circ} \mathrm{C} \mathrm{min}{ }^{-1}$ & 6.9 & 4.5 & 5.2 \\
\hline methyl cyclohexanoate & $100{ }^{\circ} \mathrm{C}$ to $180^{\circ} \mathrm{C}$ at $10^{\circ} \mathrm{C} \mathrm{min}-1$ followed by $180{ }^{\circ} \mathrm{C}$ to $200{ }^{\circ} \mathrm{C}$ at $3{ }^{\circ} \mathrm{C} \mathrm{min}{ }^{-1}$ & 6.9 & 1.5 & 9.0 \\
\hline hexyl cyclohexanoate & $100{ }^{\circ} \mathrm{C}$ to $180^{\circ} \mathrm{C}$ at $10^{\circ} \mathrm{C} \mathrm{min}^{-1}$ followed by $180{ }^{\circ} \mathrm{C}$ to $200{ }^{\circ} \mathrm{C}$ at $3{ }^{\circ} \mathrm{C} \mathrm{min}{ }^{-1}$ & 6.8 & 4.5 & 8.8 \\
\hline cyclohexyl cyclohexanoate & $100^{\circ} \mathrm{C}$ to $180^{\circ} \mathrm{C}$ at $10^{\circ} \mathrm{C} \mathrm{min}^{-1}$ followed by $180^{\circ} \mathrm{C}$ to $200^{\circ} \mathrm{C}$ at $3{ }^{\circ} \mathrm{C} \mathrm{min}-1$ & 6.9 & 5.6 & 9.0 \\
\hline
\end{tabular}

